\title{
Public Participation and the Development of Transportation Infrastructure towards Sustainable Transportation and Regional Development in Medan, North Sumatra, Indonesia
}

\author{
Andi Estetiono ${ }^{1,2}$, Badaruddin $^{1}$, Moh. Sofian Asmirza ${ }^{1}$, Rujiman ${ }^{1}$ \\ ${ }^{1}$ Universitas Sumatera Utara, Indonesia \\ ${ }^{2}$ Faculty of Vocational Studies Universitas Airlangga, Surabaya, Indonesia \\ Correspondence: Andi Estetiono. E-mail: estetiono@gmail.com
}

Received: October 11, 2017

doi:10.5539/ass.v14n1p112

\begin{abstract}
The purpose of this study is to analyze and explain the influence of public participation and the development of transportation infrastructure towards sustainable transportation and regional development in the city of Medan in North Sumatra Indonesia. This research was conducted by an explanatory approach using primary data with purposive sampling technique method based on criteria of 300 respondents. Data analysis techniques used was SEM (Structural Equation Modeling). The results of this study indicate that public participation has positive influence on sustainable transportation in the city of Medan, the development of transportation infrastructure has positive effect on sustainable transportation at the city of Medan, public participation has positive effect on the regional development in the city of Medan, the development of transportation infrastructure has positive effect on the regional development in the city of Medan, sustainable transportation has positive effect on the regional development in the city of Medan, public participation has indirect influence to the regional development through sustainable transportation in the city of Medan, and the development of transportation infrastructure has indirect influence to the regional development through sustainable transportation in the city of Medan, North Sumatra Indonesia.
\end{abstract}

Keywords: SEM, Public Participation, Development of Transportation Infrastructure, Sustainable Transportation, Regional Development

\section{Introduction}

The regional development is basically aimed to improve the welfare of the people of a region in a sustainable manner. Transportation system (sustainable transportation) is one aspect of sustainability (global sustainability), which has three interrelated components, namely: environment, society and economy. Big cities can not be separated from the transportation system if they want to grow and develop well in the future, in this occasion, we will analyze the city of Medan.

Urban areas, home to more than half of the world's population, face unprecedented transportation and mobility challenges. With rapid population and economic growth, the demands for urban mobility are steadily rising. Globally, some 8 billion trips are made every day in cities of which nearly half $(47 \%)$ are by private motorized modes. Almost all of which are propelled by fossil fuels (Pourbaix, 2011). In 2050, there may be 3 to 4 times as many passenger-kilometers travelled as half a century earlier (International Transportation Forum, Robert Cervero, 2011). Therefore, the need of infrastructure and energy is needed.

Medan is the gate of west area of Indonesia as well as the gate for the tourist to go to Brastagi in Karo highland, orangutan tourism object in Bukit Lawang and water tourism in Lake Toba. Medan is rapidly growing as the third largest city in Indonesia with high population growth, increasing activities and high mobility. However, without area enlargement, problems are occurred, especially in the regional development.

Several issues that can be recognized are the flood management, transportation, traffic jam, cleanliness and garbage handling, street vendors' arrangement, lack of open areas, slums and other issues. The handling of those issues should be conducted in well planned and coordinated actions, something that has not happened yet. A comprehensive and integrated action that involve public is something that must be done immediately. Public planning and parcipatory planning are applicable approaches that can be used so that the public feels the ownership of the city. 
Table 1. GRDP, The Population Growth and Total Area of Medan 2003 -2013

\begin{tabular}{|c|c|c|c|c|c|c|c|c|c|}
\hline \multirow[b]{2}{*}{ Year } & \multirow{2}{*}{$\begin{array}{l}\text { GRDP } \\
\text { (billion) }\end{array}$} & \multirow{2}{*}{$\begin{array}{c}\text { Economic } \\
\text { Growth } \\
(\%)\end{array}$} & \multirow[b]{2}{*}{ Population } & \multirow{2}{*}{$\begin{array}{c}\text { Area } \\
(\mathrm{Km} 2)\end{array}$} & \multirow{2}{*}{$\begin{array}{l}\text { Population } \\
\text { Density/Km }\end{array}$} & \multicolumn{4}{|c|}{ Long Road } \\
\hline & & & & & & State & Province & City & Total \\
\hline 2003 & $22.017,78$ & 5.75 & 1.993 .602 & 265,10 & 7,520 & 79,250 & 45,10 & 2.951 .380 & $3.035,41$ \\
\hline 2004 & $23.623,14$ & 7,29 & 2.006 .142 & 265,10 & 7,567 & 79,250 & 45,10 & 2.951 .380 & $3.035,41$ \\
\hline 2005 & $25.271,63$ & 6,97 & 2.036 .185 & 265,10 & 7,681 & 79,250 & 45,10 & 2.951 .380 & $3.035,41$ \\
\hline 2006 & $27.210,12$ & 7,67 & 2.067.288 & 265,10 & 7,798 & 70,920 & 45,10 & 2.951 .380 & $3.035,41$ \\
\hline 2007 & $29.352,92$ & 7,87 & 2.083 .156 & 265,10 & 7,858 & 79,520 & 45,10 & 2.951 .380 & $3.035,41$ \\
\hline 2008 & $31.334,34$ & 6,75 & 2.102 .105 & 265,10 & 7,929 & 79,520 & 45,10 & 2.951 .380 & $3.035,41$ \\
\hline 2009 & $33.430,69$ & 6,69 & 2.121 .053 & 265,10 & 8,001 & 79,520 & 45,10 & 2.951 .380 & $3.035,41$ \\
\hline 2010 & $35.822,22$ & 7,15 & 2.097 .610 & 265,10 & 7,913 & 140,70 & 11,94 & 3.017 .400 & $3.170,04$ \\
\hline 2011 & $38.576,23$ & 7,68 & 2.117 .224 & 265,10 & 7,987 & 121,40 & 24,48 & 3.032 .560 & $3.102,32$ \\
\hline 2012 & $41.519,32$ & 7,62 & 2.122 .804 & 265,10 & 8,008 & 111,80 & 33,20 & 2.951 .380 & $3.096,38$ \\
\hline 2013 & $44.696,27$ & 7,65 & 2.123 .210 & 265,10 & 8,009 & 73,030 & 40,20 & 2.951 .380 & $3.064,61$ \\
\hline
\end{tabular}

Table 1 shows the population growth of Medan in the last 12 years, from 1,993,602 in 2003 became 2,497,187 in 2014. That means the population had increased about half million people. On the other hand, the total area is still the same $(265,100 \mathrm{~m} 2)$. This is the fact that stirs various issue as described by Prof. Sirojuzilan in his book "Problematics of urban and regional areas" 2011. This population growth is of course followed by the increase of activities, mobilities, and various life requirements as clothing, food and home.

Various aspect of area development will surely cause transportation issue as happened in many big cities in Indonesia; issues that including network operational aspects, financial, economy, environment and health. The indications of those problems can be seen in traffic jam, the increase of proportion of personal usage, high level of accidents, inefficient consumption of fuel and etc. The regional development issues remind us that transportation problem requires participation from public, comprehensive thoughts and handling with emphasis on increasing the efficiency and effectiveness of the existing infrastructures, and optimize the limited resources in order of transportation system development to anticipate the area increasing (Sjafruddin, 2011).

Table 2. Personal and Public Transportation in Medan 2004 - 2013

\begin{tabular}{cccccc}
\hline \multirow{2}{*}{ Year } & $\begin{array}{c}\text { Passenger Car } \\
\text { (amount and } \\
\text { growth) }\end{array}$ & $\begin{array}{c}\text { Car Cart } \\
\text { (amount and } \\
\text { growth) }\end{array}$ & $\begin{array}{c}\text { Bus } \\
\text { (amount and } \\
\text { growth) }\end{array}$ & $\begin{array}{c}\text { Motorcycle } \\
\text { (amount and } \\
\text { growth) }\end{array}$ & Total \\
\hline \multirow{2}{*}{2004} & 140.302 & $104.776(5,34 \%)$ & 12.108 & 756.560 & 1.022 .755 \\
& $(8,04 \%)$ & $(5,34 \%)$ & $(5,34 \%)$ & $(5,34 \%)$ \\
2005 & 164,134 & 112.001 & 12.406 & 883.406 & 1.172 .127 \\
& $(14,02 \%)$ & $(6,89 \%)$ & $(2,46 \%)$ & $(16,76 \%)$ & $(14,6 \%)$ \\
2006 & 175.198 & 116.184 & 12.619 & 985.745 & 1.289 .746 \\
& $(6,62 \%)$ & $(3,73 \%)$ & $(2,46 \%)$ & $(16,76 \%)$ & $(10 \%)$ \\
2007 & 189.157 & 120.328 & 12.751 & 1.103 .707 & 1.425 .943 \\
& $(7,96 \%)$ & $(3,56 \%)$ & $(2,46 \%)$ & $(11,96 \%)$ & $(10.55 \%)$ \\
2008 & 209.527 & 140.986 & 22.130 & 2.104 .026 & 2.476 .669 \\
& $(11,80 \%)$ & $(17,20 \%)$ & $(73,60 \%)$ & $(90,60 \%)$ & $(73,68 \%)$ \\
2009 & 222.891 & 144.865 & 22.123 & 2.318 .632 & 2.708 .511 \\
& $(6,40 \%)$ & $(2,80 \%)$ & $(-7 \%)$ & $(10.20 \%)$ & $(9,36 \%)$ \\
2010 & 241.012 & 149.182 & 21.680 & 2.914 .520 & 3.326 .394 \\
& $(8,13 \%)$ & $(2,98 \%)$ & $(-2 \%)$ & $(25,7 \%)$ & $(22,81 \%)$ \\
& 268.198 & 154.657 & 22.013 & 3.464 .198 & 3.909 .066 \\
& $(11,28 \%)$ & $(3,67 \%)$ & $(-1,54 \%)$ & $(18,86 \%)$ & $(17,52 \%)$ \\
& 293.945 & 158.987 & 22.277 & 4.188 .215 & 4.663 .424 \\
& $(9,6 \%)$ & $(2,80 \%)$ & $(-1,20 \%)$ & $(20,9 \%)$ & $(14,76 \%)$ \\
\end{tabular}

Source: Medan Statistic Biro (BPS), Department of Transportation of Medan 2015 
The number of personal and public transportation in Medan has increased in the last 10 years from 1,022,755 units in 2004 to become 5,381,566 units in 2013 or 4,358,811 units increasing (426\%) as described in Tabel 2. On the other hand, the road length in Medan had only increased 29,2 km (0,096\%). In 2003, the road length in Medan (state, province and city properties) was $3.035,41 \mathrm{~km}$ and became $3.064,61 \mathrm{~km}$ in 2013, which was barely grown. This condition will become even harder in the future without proper handling. Not to mention, the centre of economy, social, cultural and politics is the city area that causes a high increase of transportation's sector.

ANTARA News (2013) published the wasted social cost that caused by traffic jam in Jakarta Indonesia and the surroundings which was approximately 68 trillion rupiahs annually. How about Medan? Are there any calculation about the wasted cost? Analisa News (2014) published the lost social cost alone caused by traffic jam at Medan North Sumatra Indonesia was 5,2 trillion annually. These 68 trillion and 5,2 trillion are huge amount which will bring great benefits should they are allocated to improve the welfare of the society, education health system and or to develop infrastructures and public facilities. Therefore, for a better future development of areas in Medan, there must be knowledge about the effect of public's participation role, development of transportation's infrastructures, and well integrated sustainable transportation to be able to create a successful regional development of Medan with more benefits for all parties in long term.

Referring to the description of problems and possibility of problems that may be faced by Medan in the future, the researchers present the title of research "Public Participation and The Development of Transportation Infrastructure towards Sustainable Transportation and Regional Development in Medan, North Sumatra, Indonesia".

\section{Method}

\subsection{Conceptual Frame of Research}

Based on the purpose of the research and literatures study that had explained in previous chapter, the conceptual frame of research as follows:

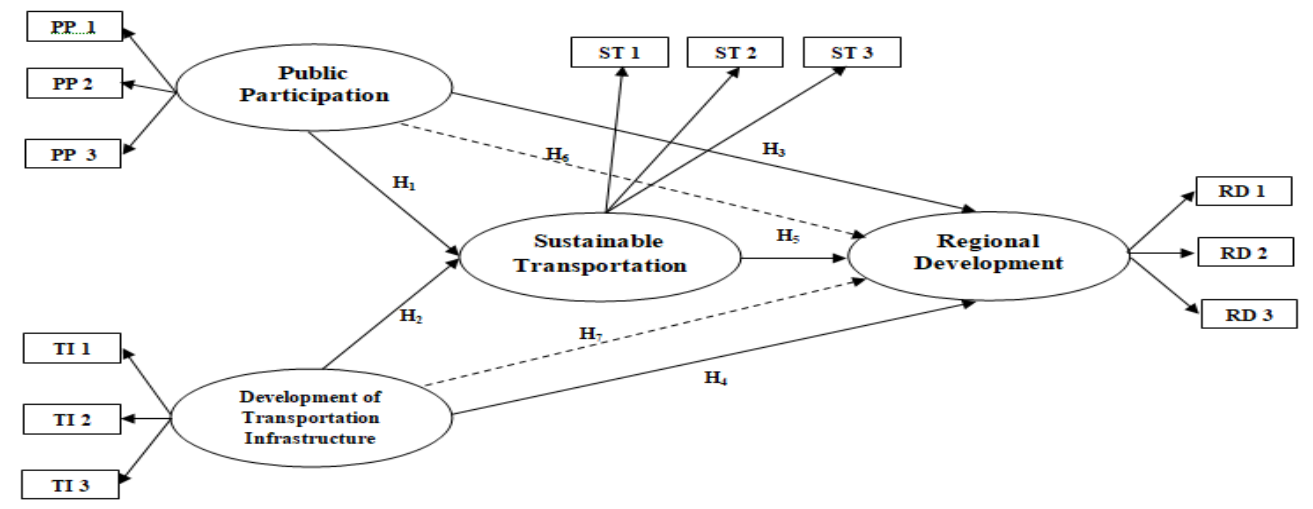

Figure 1. Conceptual Framework

Description of Symbols

$\rightarrow \quad$ : Direct Impact

$\rightarrow \quad$ : Indirect Impact

Public Participation

$\mathrm{PP}_{1}$ : Decision Making

$\mathrm{PP}_{2}$ : Implementation

$\mathrm{PP}_{3}$ : Evaluation

The Development of Transportation's Infrastructure

$\mathrm{TI}_{1}$ : Physical Hard Infrastructure

$\mathrm{TI}_{2}$ : Non-Physical Hard Infrastructure

$\mathrm{TI}_{3}$ : $\quad$ Soft Infrastructure

Sustainable Transportation

$\mathrm{ST}_{1}: \quad$ Social

$\mathrm{ST}_{2}$ : Economy 
$\mathrm{ST}_{3}: \quad$ Environment

Regional Development

$\mathrm{RD}_{1}$ : $\quad$ Enhancement of Local Revenues

$\mathrm{RD}_{2}$ : Economical Growth

$\mathrm{RD}_{3}$ : Labor

Public participation is an active involvement of the society in the process of decision making, application, result's utilization and evaluation. Regarding that, the public participation can be described as involvement of public in ideas, mentally and emotionally during the process of decision making, implementation, result's utilization and evaluation of development of Medan. The indicators of public participation in this research were measured by (1) decision making; (2) implementation and (3) evaluation.

\subsection{Research Design}

This is an explanatorial research, that is a research that conducted by explaining generated symptoms of the research object, and aim to explain the causality relation. This is to find whether there is connection between public participation and the development of transportation infrastructure towards sustainable transportation and regional development at Medan North Sumatra Indonesia.

\subsection{Time and Location of Research}

The location of this research was in centre area, middle area, and suburban area of Medan. It was specifically conducted in main stations in Medan and also several offices for principals and staffs of related institutions; Regional Planning Agency (Badan Perencanaan Daerah), Land Transportation Employers' Organization (Organisasi Angkutan Darat), Department of Transportation (Dinas Perhubungan), Public Transportation Organization of Indonesia (Masyarakat Transportasi Indonesia), Cooperative Public Transportation of Medan (Koperasi Pengangkutan Umum Medan). The time of research was started on June 2016 until September 2016.

\subsection{Population and Samples}

Population of this research was citizen of Medan North Sumatra Indonesia. The number of citizens in 2015 was $2,468,429$; consisted of $1,241,826$ males and 1,226,603 females. The objects of this research were stakeholders of public transportation (public, users, owners, and other related stakeholders) that related to the research. The sampling collection method of this research was non-probability sampling technique (purposive sampling), which was one of the sample collection techniques that was purposively conducted based on certain criteria from the researchers. The researchers decided the taken samples based on certain criteria or consideration that was related to the research. The criteria were as follows:

1. Drivers of public transportation in Medan and surrounding.

2. Users of public transportation in Medan and surrounding.

3. Drivers of becak motor (pedicab) in the Medan area.

4. The owners of public transportation in Medan and surrounding.

5. Committees and or members of ORGANDA of Medan (Organisasi Angkutan Darat).

6. Committees and or members of MTI of Medan (Masyarakat Transportasi Indonesia)

7. Committees and or members of KPUM of Medan (Koperasi Pengangkutan Umum Medan)

8. Officials and staffs of department of transportation of Medan (Dinas Perhubungan)

9. Officials and staffs of urban planning of Medan (Perencanaan Kota)

10. Officials and staffs of bina marga of Medan (Dinas Pekerjaan Umum)

11. Officials and staffs of BAPPEDA of Medan (Badan Perencanaan Daerah)

The number of respondents was decided according to Roscoe opinion (Sugiono, 2003), that mentioned that regardless the population number in social research, the appropriate number of samples should be between 30 to 500 persons. The determination of sample numbers used Slovin formula because the number population in this research was known (Sangadji et.al., 2010). The Slovin formula is :

$$
n=N /\left(1+N e^{2}\right)
$$

Note 
$\mathrm{n}=$ samples number

$\mathrm{N}=$ population size

$\mathrm{e}=$ Percentage of allowance because of mistakes in sample collection that can be tolerated (10\%).

The number of population (N) in the research is 2,468,429 of citizens of Medan in 2015, with the mistake assumption (e) of $10 \%$, the minimum sample numbers to be used in this research is:

$$
n=\left(\frac{2,468,429}{1+2,468,429(0.10)^{2}}\right)
$$

$\mathrm{n}=100.0$

The minimum number of samples chosen was 100 persons to anticipate the outlier sample data (not suitable with the need of data measurement) and also because there will be application of maximum likehood estimation technique, it will require 300 samples. Based on that opinion, the sample numbers will be 300 respondents related to the research.

\subsection{Data Analysis Technique}

The analysis technique used to answer the hypothesis test is Structural Equation Model (SEM) with programme AMOS 21.0 and SPSS 15.0. Structural Equation Model (SEM) is a series of statistical techniques that enable test of a sequence of relatively complicated relations simultaneously (Ferdinand, 2000: 3). Steps of SEM development are as follows:

1. Theory-based model development.

2. Development of line chart to show a casuality relation.

3. Conversion of line chart into series of structural equation and measurement model specification.

4. Choosing of input matrix and estimation technique regarding developed model.

5. Evaluating identification issue.

6. Model evaluation with goodness-of-fit criteria.

7. Interpretation and model modification.

\subsection{Hypothesis}

Hypothesis is temporary assumptions using prior to the research (Sugiyono, 2010:84). A research hypothesis is the statement created by researchers when they speculate upon the outcome of a research or experiment (Martyn Shuttleworth). Based on the above conceptual frame figure, the hypothesis can be formulated as follows:

$\mathrm{H}_{1}$ : The public participation is positively affecting the sustainable transportation in Medan.

$\mathrm{H}_{2}$ : The development of transportation's infrastructures is positively affecting the sustainable transportation in Medan.

$\mathrm{H}_{3}$ : The public participation is positively affecting the regional development of Medan.

$\mathrm{H}_{4}$ : The development of transportation infrastructures is positively affecting the regional development in Medan.

$\mathrm{H}_{5}$ : The sustainable transportation is positively affecting the regional development in Medan.

$\mathrm{H}_{6}$ : The public participation is indirectly affecting the regional development through sustainable transportation in Medan.

$\mathrm{H}_{7}$ : The development of transportation's infrastructures is indirectly affecting the regional development through sustainable transportation in Medan.

\section{Results}

\subsection{Confirmatory Factor Analysis}

The CFA test was intended to know whether the indicators are representative enough to shape each inherent variable including Public Participation (X1), Transportation Infrastructure development (X2), Sustainable Transportation (Y1) and Regional Development (Y2); all with the help of AMOS 21.0

\subsubsection{CFA of Public Participation Variable (X1)}

The data processing result of confirmatory analysis of Public Participation can be seen in figure 2 as follows: 


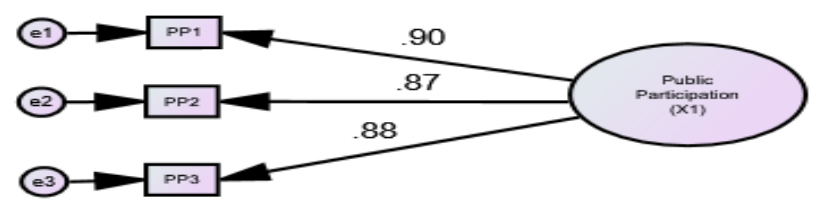

Figure 2. Confirmatory analysis of Public Participation

Based on the confirmatory analysis in figure 2 , the variable indicators of public participation consist of decision making (PP1), implementation (PP2), and evaluation (PP3) have convergent validity score (loading factor) above 0,5 . That means all three indicators are eligible to shape the public participation variable.

\subsubsection{CFA of Transportation Infrastructure Development Variable $\left(\mathrm{X}_{2}\right)$}

Data processing result of confirmatory analysis of transportation infrastructure development can be seen in figure 3, as follows:

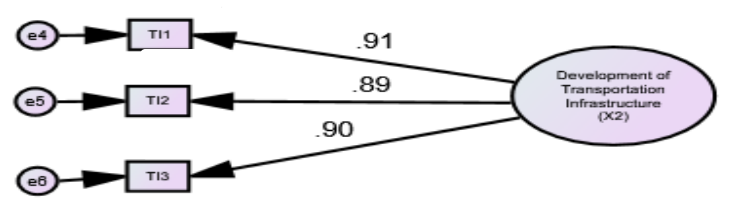

Figure 3. Confirmatory Analysis of Trasnportation Infrastructure Development

Based on confirmatory analysis in figure 3, variable indicators of transportation's infrastructure development that consists of physical hard infrastructure (TI1), non-physical hard infrastructure, (TI2) and soft infrastructure (TI3) are in convergent validity value (loading factor) above 0,5 . Those three indicators are eligible to shape the variable of transportation's infrastructure development.

\subsubsection{CFA Variable of Sustainable Transportation}

Data processing result of confirmatory analysis of sustainable transportation can be seen in figure 4 as follows:

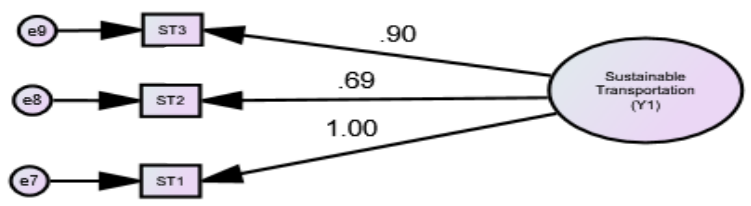

Figure 4. Confirmatory Analysis of Sustainable Transportation

Based on confirmatory analysis in figure 4 , the variable indicators of sustainable transportation that consists of social (ST3), economy (ST2), and environment (ST1) are in convergent validity value (loading factor) above 0,5. That means those three indicators are eligible to shape the variable of sustainable transportation

\subsubsection{CFA of Regional Development Variable}

The data processing result of confirmatory analysis of regional development can be seen in figure 5 as follows

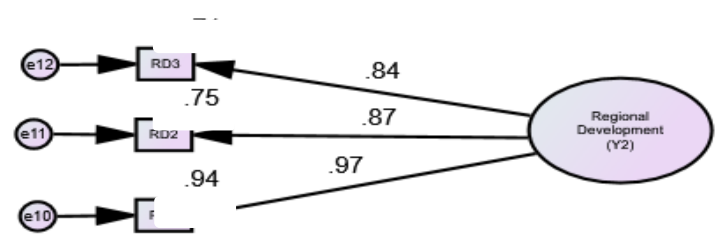

Figure 5. Confirmatory Analysis of Regional Development

Based on confirmatory analysis in figure 5 , the variable indicators of regional development consist of increasing of district own revenue (RD1), economical growth (RD2), and labors (RD3) are in convergent validity value (loading factor) above 0,5 . That means those three indicators are eligible to shape the variable of regional development. 


\subsection{Construct Reliability and Variance Extract Test}

The test result of construct reliability can be seen in table 3 that explained the construct reliability of latent variables in this research as follows;

Table 3. Test Result of Construct Reliability

\begin{tabular}{|c|c|c|c|c|c|c|}
\hline Construct & Indicators & Standardize Factor Loading & SFL Kuadrat & Error $[\varepsilon j]$ & $\begin{array}{l}\text { Construct } \\
\text { Reliability }\end{array}$ & $\begin{array}{l}\text { Variance } \\
\text { Extrated }\end{array}$ \\
\hline Public & PP 1 & 0.900 & 0.810 & 0.190 & & \\
\hline Participation & PP 2 & 0.874 & 0.764 & 0.236 & 0.916 & 0.78 \\
\hline (X1) & PP 3 & 0.881 & 0.776 & 0.224 & & \\
\hline Development & TI 1 & 0.908 & 0.824 & 0.176 & & \\
\hline of Transportation & TI 2 & 0.886 & 0.785 & 0.215 & 0.926 & 0.81 \\
\hline Infrastructure (X2) & TI 3 & 0.900 & 0.810 & 0.190 & & \\
\hline Sustainable & ST 1 & 0.995 & 0.990 & 0.010 & & \\
\hline Transportation & ST 2 & 0.690 & 0.476 & 0.524 & 0.901 & 0.76 \\
\hline$(\mathrm{Y} 1)$ & ST 3 & 0.897 & 0.805 & 0.195 & & \\
\hline Regional & $\mathrm{RD} 1$ & 0.968 & 0.937 & 0.063 & & \\
\hline Development & $\mathrm{RD} 2$ & 0.868 & 0.753 & 0.247 & 0.922 & 0.80 \\
\hline$(\mathrm{Y} 2)$ & RD 3 & 0.841 & 0.707 & 0.293 & & \\
\hline Limit Accetable & & & & & $\geq 0.7$ & $\geq 0.5$ \\
\hline
\end{tabular}

Source: data processing result using AMOS 21.00, 2017

Table 3 shows that the result of internal consistency reliability test for every construct indicated good result, that is the coefficient of cosntruct reliability achieved is suitable wis the appropriate limitation $>0.7$ (Ferdinand, 2002:193).

\subsection{Result of AMOS}

AMOS or measurement model testing. Model measurement is part of SEM model that consist of latent variable (construct) and several manifest variables (indicators). The purpose of test is to see how exact those manifest variables are able to explain the existing latent variable. The test result can be seen in figure 6 and tabel 4 .

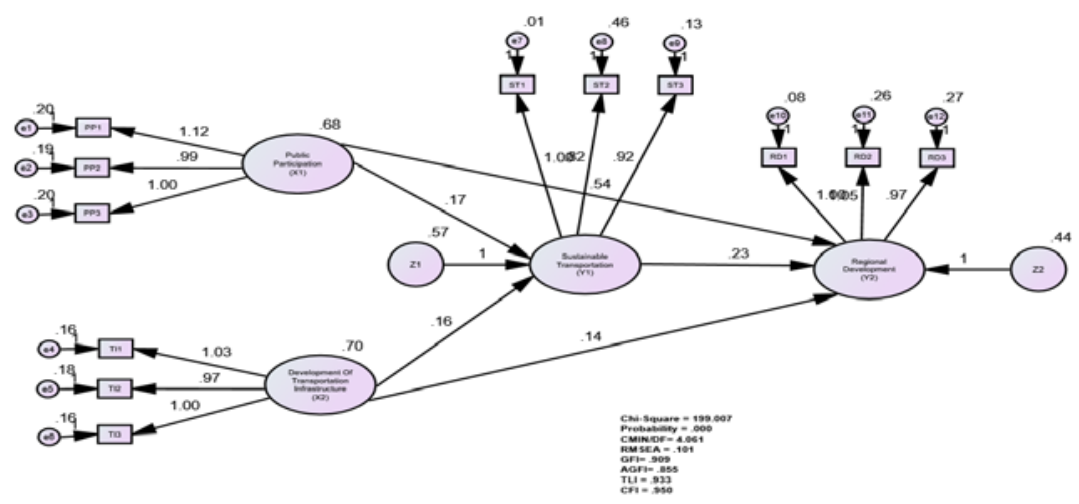

Figure 6. Measurement Model before Modification

Table 4. Evaluation of criteria Goodness of Fit Indices before Modification Model

\begin{tabular}{cccc}
\hline Criteria & Results & Critical Values & Model Evaluation \\
\hline Chi-Square & 199.007 & $\leq \chi^{2}$ tabel $(85.351)$ & Not Fit \\
Probability & 0.000 & $\geq 0,05$ & Not Fit \\
CMIN/DF & 4.061 & $\leq 2,00$ & Not Fit \\
RMSEA & 0.101 & $\leq 0,08$ & Not Fit \\
GFI & 0.909 & $\geq 0,90$ & Not Fit \\
AGFI & 0.855 & $\geq 0,90$ & Not Fit \\
TLI & 0.933 & $\geq 0,95$ & Marginal Fit \\
CFI & 0.950 & $\geq 0,94$ & Marginal Fit \\
\hline
\end{tabular}

Source: data processing result using AMOS 21.00, 2017 
The calculation result of SEM model had yielded index goodness of fit as shown in tabel 4. Based in tabel 4, the chi-squares value and probability is showing a slightly bad result. But then the chi-squares value are highly sensitive to the amount of samples, and the RMSEA value is quite bad.

Therefore, it is recommended to apply SEM model modification. The result of SEM modification can be seen in figure 7 and table 5

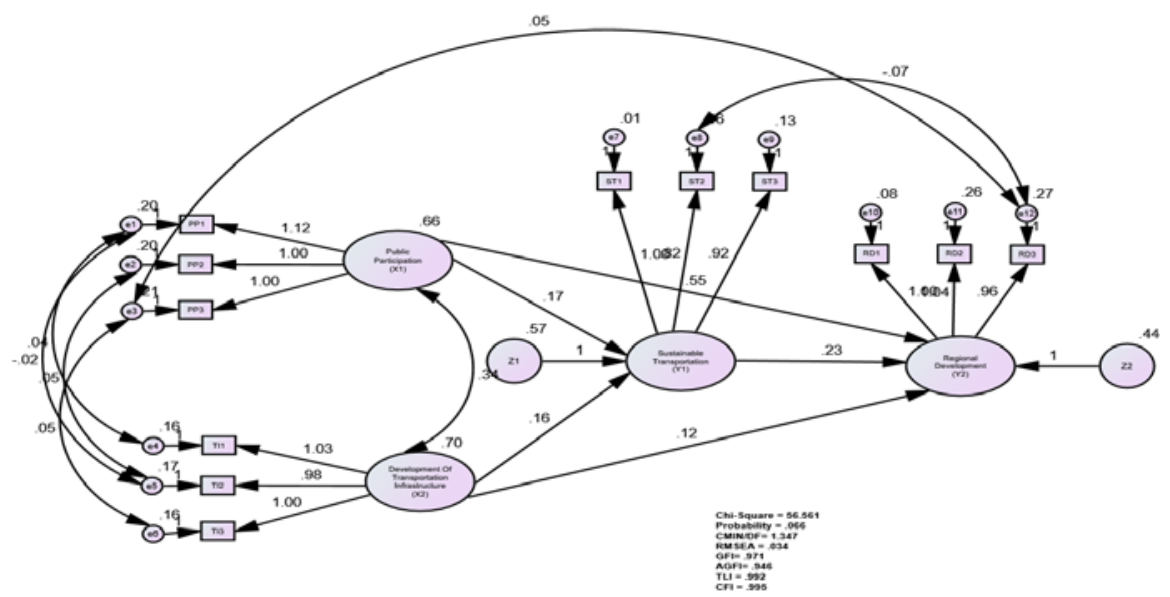

Figure 7. Model Measurement after Modification

Table 5. Criteria Evaluation Goodness of Fit Indices after Model Modification

\begin{tabular}{cccc}
\hline Criteria & Results & Critical Values & Model Evaluation \\
\hline Chi-Square & 56.561 & $\leq \chi^{2}$ tabel $(74.745)$ & Fit \\
Probability & 0.066 & $\geq 0,05$ & Fit \\
CMIN/DF & 1.347 & $\leq 2,00$ & Fit \\
RMSEA & 0.034 & $\leq 0,08$ & Fit \\
GFI & 0.971 & $\geq 0,90$ & Fit \\
AGFI & 0.946 & $\geq 0,90$ & Fit \\
TLI & 0.992 & $\geq 0,95$ & Fit \\
CFI & 0.995 & $\geq 0,94$ & Fit \\
\hline
\end{tabular}

Source: data processing result using AMOS 21.00, 2017

\subsection{Hypothesis Testing}

\subsubsection{Direct Effect Analysis}

The test result of direct effect hypothesis that submitted for this research is briefly shown in tabel 6 .

Table 6. Direct Effect Hypothesis Testing Result

\begin{tabular}{cccccccc}
\hline \multicolumn{2}{c}{ Hipotesis Direct Effect } & Estimate & S.E. & C.R. & P & Information \\
\hline Y1 & $<---$ & $\mathrm{X} 1$ & .173 & .067 & 2.590 & .010 & Significant \\
Y1 & $<---$ & $\mathrm{X} 2$ & .159 & .064 & 2.473 & .013 & Significant \\
Y2 & $<---$ & $\mathrm{Y} 1$ & .230 & .056 & 4.130 & $* * *$ & Significant \\
$\mathrm{Y} 2$ & $<---$ & $\mathrm{X} 1$ & .553 & .066 & 8.442 & $* * *$ & Significant \\
$\mathrm{Y} 2$ & $<---$ & $\mathrm{X} 2$ & .123 & .061 & 1.996 & .046 & Significant \\
\hline
\end{tabular}

Source: data processing result using AMOS 21.00, 2017.

Table 6 shows the result of direct effect hypothesis testing, explained as follows:

1. Public participation (X1) is positively affecting sustainable transportation (Y1). It can be seen from positive marked path coefficient of 0,173 with C.R. value of 2,590. There is also positive probability of 0,010 that is bigger than the determined positive level of 0,05 . It is concluded that public participation is positively affecting sustainable transportation. The first hypothesis that mentioned "public participation is positively affecting the sustainable transportation in Medan" is proven.

2. The transportation infrastructure development (X2) is positively affecting sustainable transportation (Y1). It can be seen from positive marked path coefficient of 0,159 with C.R. value of 2,473 . There is also positive 
probability of 0,013 that is bigger than the determined positive level $(\alpha)$ of 0,05 . It is concluded that transportation infrastructure development is positively affecting sustainable transportation. The second hypothesis that mentioned "transportation infrastructure development is positively affecting the sustainable transportation in Medan" is proven.

3. Public participation (X1) is positively affecting regional development (Y2). It can be seen from positive marked path coefficient of 0,553 with C.R. value of 8,442 . There is also positive probability of 0,000 that is bigger than the determined positive level $(\alpha)$ of 0,05 . It is concluded that public participation is positively affecting area development. The third hypothesis that mentioned "public participation is positively affecting the regional development in Medan" is proven.

4. Transportation infrastructure development (X2) is positively affecting regional development (Y2). It can be seen from positive marked path coefficient of 0,123 with C.R. value of 1,996 . And there is also positive probability of 0,046 that is bigger than the determined positive level $(\alpha)$ of 0,05 . It is concluded that transportation infrastructure development is positively affecting regional development. The fourth hypothesis that mentioned "transportation infrastructure development is positively affecting the regional development in Medan" is proven.

5. Sustainable transportation (Y1) is positively affecting regional development (Y2). It can be seen from positive marked path coefficient of 0,230 with C.R. value of 4,130 . And there is also positive probability of 0,000 that is bigger than the determined positive level $(\alpha)$ of 0,05 . It is concluded that sustainable transportation is positively affecting area development. The fifth hypothesis that mentioned "sustainable transportation is positively affecting regional development in Medan" is proven.

\subsubsection{Indirect Effect Analysis}

Test result of indirect effect hypothesis proposed in this research is briefly shown in tabel 7 .

Table 7. Indirect Effect Hypothesis Testing Result

\begin{tabular}{ccccc}
\hline & $\mathrm{X} 2$ & $\mathrm{X} 1$ & $\mathrm{Y} 1$ & $\mathrm{Y} 2$ \\
\hline $\mathrm{Y} 1$ & .000 & .000 & .000 & .000 \\
$\mathrm{Y} 2$ & .037 & .040 & .000 & .000 \\
\hline
\end{tabular}

Source: data processing result using AMOS 21.00, 2017

Table 7 shows the testing result of indirect effect hypothesis that explained as follows:

6. Public participation (X1) is indirectly affecting regional development (Y2) through sustainable transportation (Y1). It can be seen from the positive marked path coefficient of indirect effect of 0,040 . The sixth hypothesis that mentioned "public participation is positively affecting regional development through sustainable transportation in Medan" is proven.

7. Transportation infrastructure development (X2) is indirectly affecting regional development (Y2) through sustainable transportation (Y1). It can be seen from the positive marked path coefficient of indirect effect of 0,040 . The seventh hypothesis that mentioned "transportation infrastructure development is positively affecting regional development through sustainable transportation in Medan" is proven.

\section{Discussions}

\subsection{The effect of public participation to sustainable transportation}

Based on data analysis result and findings in research, there is conclusion that public participation is positively and significantly affecting the sustainable transportation, so it can be said that first hypothesis "public participation is positively affecting sustainable transportation in Medan" is proven.

The result of this research is acknowledged that public participation is positively affecting sustainable transportation, according to opinion of A.R. Barter Tamin Raad (2000) who mentions sustainable transportation system must possess principles that ensures enough access to all part of society including the disables, children and elderly to at least acquire their basic needs as healthcare, education and job opportunity. Transportation system was provided for public, therefore public must have enough portion to participate in deciding the transportation mode and also to involve in the procurement process. Every level of society must be included, regardless their capability to possess certain transportation facilities such as car or motorcycle. This participation must be nurtured so that their opinion is calculated in the process of planning, implementation and management of transportation system of the city. Transparency is one important thing to keep. Availability and transparency of information during the process is a warrant for the conduct of good and public oriented system. 


\subsection{The effect of transportation infrastructure development to sustainable transportation}

Data analysis result and findings shown that transportation infrastructure development is positively and significantly affecting the sustainable transportation, so it is concluded that second hypothesis "transportation infrastructure development is positively affecting sustainable transportation in Medan" is proven. The result of this research means transportation infrastructure developments will positively affect sustainable transportation. The article deals with the problem of the impact of transportation infrastructure on sustainable living environment. Transportation infrastructure, its components, relations with other objects, even participants play a great role in the formation of an attractive living environment. The influence of transportation infrastructure on the living environment can be described by the number of indicators which are determined and systemized while preparing development projects (Aušrine, 2015). The result of this research is in accordance with study from Lining (2007:16) that mentioned the role of transportation infrastructure as determinant of modeled common location based on accessibility concept. the accessibility steps of difficulty to reach certain area, and that is regardless the quantity and quality of transportation infrastructure.

\subsection{The effect of public participation to regional development}

The data analysis result and findings from this research shows that public participation is positively and significantly affecting the regional development, so that the third hypothesis "public participation positively affecting the regional development in Medan" is proven. This finding means the public participation will give positive effect to the regional development. The public participation that supports various decisions regarding to the regional development will support the process of achieving the regional development's target. The result of this research supports the statement of Arnstein (1969) that mentioned that participation as power redistribution will enable those whose economically and politically marginalized to be deliberately getting involved in the planning of the future development. The strategy of participation application is reached by involving public in information sharing, goal formulation, policies setting, funding resources allocation, operational of program and distribute the gained benefits. In other words, it should be involving public since the planning until implementation and the equity spreading of the results and including the controlling phase.

According to Sukawi (2010), the involvement of public in public consultation is a role manifestation of public regarding spatial planning, that in term of suggestion, advice or objection to the government. It is also stated in the opinion of Ericson (in Slamet, 1994) that participation in the stage of implementation is an involvement of a person in the work stages of a project. Sutami (2009) mentioned that the activities of public to participate in development is quite strong in PPMK.

\subsection{The effect of transportation infrastructure development to regional development}

The data analysis result and research finding showed that transportation infrastructure development positively and significantly affects the regional development, so that the fourth hypothesis "transportation infrastructure development is positively affecting the regional development in Medan" is proven. This research's finding means that the sustainable transportation infrastructure development will bring positive impact to the regional development. Along with the increasing of Indonesian population that in 2035 will double from the number of population in 10 years ago or approximately 400 million people, it had brought concern about "food scarcity" condition in the future. Furthermore, along with the growing level of education and welfare of people, there will also be an increasing of per capita consumption for various food, which is in 35 years later Indonesia will need additional food availability in almost 2 times of cuurent need (Siswono Yudohusodo, 2002). Traditionally, the impact of transportation infrastructure development is assessed in technical, economic, financial, environmental aspects and those of road safety and land use Burinskiene et al. 2007). From a technical point of view, the attention is primarily paid to the physical development level of the infrastructure gauge: whether transportation needs are evaluated according to mobility trends, whether the realization of transportation means is determined in applying an existent or installing a new technical infrastructure (streets, sidewalks, public transportation stations, car parks). (Aušrinè, 2015).

\subsection{The effect of sustainable transportation to regional development}

Data analysis result and research' findings showed that the sustainable transportation significantly and positively affects the regional development, so the fifth hypothesis "Sustainable transportation is positively affecting the regional development in Medan" is proven. This research's findings mean that the sustainable transportation will positively affecting the regional development. According to Lawrence W. LAN research, in transportation sector, some important undertakings for sustainability are also examined. To be sustainable, overall transportation systems including infrastructures, vehicles, operation and maintenance must not endanger the public health or ecosystems while meeting the mobility needs. They must at least comply with two basic principles: use of 
renewable resources at below their rates of regeneration and use of non-renewable resources at below the rates of development of renewable substitutes.

The research of Sunardi (1999) in Magelang region has proved that accessibility factor is the area potential factor that closest related with the service facilities availability compared with other area's potential factor. The accessibility factor was determined by comparing areas wide-ranging with road's length. In other word, the more crowded the transportation line is the bigger possibility is the avaiability of service facilities.

\subsection{The effect of public participation to regional development through sustainable transportation}

The result and finding of the research declared that the public participation is indirectly affecting regional development in Medan through sustainable transportation. That means the public participation had of course through several ways, that is participation in decision making, the participation in proposing ideas in strategy and policy decision in the management of public transportation in Medan. The next is public participation in investment, That means public must be actively involved in the operational such as involved in the procurement process, and to decide the route of the transportation to avoid any route's overlapping that leads to conflict. Some crowded routes are packed with numbers of transportation owners, and the less crowded routes are less interesting for the business owners. Another problem arise is the number of unregistered public trasnportation that increased and caused conflict with the registered transportation owners. Also, the increasing number of illegal station in Medan. Regarding those issues, there are urgent need for supervision and strict law enforcement to those who breaks the regulation. The third is through the public participation in the evaluation of public transportation's performance. That means the public participation in term of providing inputs should have their best opportunity by creating regular meeting forum and forum for the owners of public transportation.

4.7 The effect of transportation infrastructure development to the regional development through sustainable transportation

The result and finding of this research declared that there is an effect of development of transportation infrastructure of regional development through sustainable transportation. It showed that the sustainable transportation system is a basic element of infrastructure that affecting the development pattern of the city. The transportation development and spatial planning are holding an important role in policy and program of the government. The infrastructure development in transportation sector will need high cost without proper management. With the good management, the increasing of Level of Service will only be temporary. The service's improvement will corelate with the increasing of business activities, which will generate more traffic activity. Social transportation's sustainability in this discussion is the comfortable sense of the public to acquire the public transportation to support their daily activities, the availability of transportation in appropriate places that serves many destinations. The number of public transportation vehicles in Medan is 6,695 units with 240 permits. This number is at the moment considered enough to supply the need of public transportation, but unfortunately the spreading is still uneven. There is also certainty of travelling time, the comfort and security during travelling.

Grigg (1988) mentioned that the role of infrastructure as mediator between social and economy system with the support of nature's environmental. Less functioned infrastructures, especially transportation infrastructure will affect the daily life. On the other hand, the overly provided infrastructures that neglecting the support ability of the environment will eventually bring damage to the nature and human as well as other living creatures.

\section{References}

Alavi, M., \& Ghaemi, H. (2011). Application of Structural Equation Modeling in EFL Testing: A Report of Two Iranian Studies. Language Testing, 1. https://doi.org/10.1186/2229-0443-1-3-22.

Anderson, J. C., \& Gerbing. D. W. (1984). The effect of sampling Error on covergent, improper solution, and goodness of fit indices for maximum likelihood factor analysis. Psychometrica, 49. https://doi.org/10.1007/BF02294170.

Andriani, Y. (2013). Penilaian Sistem Transportationasi yang Mengarah Pada Green Transportationasi di Kota Surakarta. Semarang: Biro Penerbit Planologi Undip.

Ang, G., \& Marchal, V. (2013). Mobilising Private Investment in Sustainable Transportation: The Case of Land- Based Passenger Transportation Infrastructure. OECD Environment Working Papers, 56. http://doi.org/10.1787/5k46hjm8jpmv-en.

Arnstein, S. R. (1969). A Ladder of Citizen Participation. JAIP, (35), 216-224, http://dx.doi.org/10.1080/01944366908977225

Assis, U. W., \& Silva, G. W. (2012). VLT: A sustainable solution ti urban mobility. Joăo Pessoa-PB, Work 41 2169-2174. DOI: 103233/WOR-2012-1022-2169. 
Bentler, P. M. (1995). EQS: Structural equation program manual. Encino, CA: Multivariat Software Inc.

Bertolini, Ll, Clercq, F., \& Kapoen, L. (2005). Sustainable accessibility: a conceptual framework to integrate transportation and land use plan-making: Two test-applications in the Netherlands and a reflection on the way forward. Transportation Policy, 12. doi:10.1016/j.tranpol.2005.01.006.

Black, J. A., Paez, A., \& Suthanaya, P. A. (2002). Sustainable urban transportation: Performance Indicators and Some Analytical Approaches. https://doi.org/10.1061/(ASCE)0733-9488(2002)128:4(184)

Bollen, K. A. (1989). Structural Equations with Latent Variables. New York: John Wiley and Sons.

Byrne, B. M. (2001). Structural equation modeling with AMOS basic concept, application and programming. Lawrence Erlbaum Associates. ISBN 978-0-8058-6372-7

Cohen, J. M., \& Uphoff, N. T. (1977). Rural Development Participation. New York: Cornel University RDCCIS

Coromina, L. (2014). Introduction to Structural Equation Modeling with Amos. University of Girona, Spain.

Daniel, W. B. (2005). Economic Interest \& Institution. The Foundation of Public Policy. Oxford Brazil Blackwell.

Detr. (1998). Sustainable Development: Opportunities for change. London: Department of the Environment, Transportation and the Regions.

Dwiningrum, S. I. A. (2011). Desentralisasi dan Partisipasi Masyarakat dalam Pendidikan. Yogyakarta: Pustaka Belajar.

Gallagher, M., \& Brown, T. (2013). Introduction to confirmatory factor analysis and structural equation modeling. Handbook of Quantitative Methods for Educational Research, 289-314. https://doi.org/10.1007/978-94-6209-404-8_14.

Ghozali, I. (2014). Model Persamaan Struktural; Konsep dan Aplikasi, dengan program AMOS 22.0, Update Bayesian SEM. Semarang: Badan Penerbit Universitas Diponegoro.

Goldman, T., \& Gorham, R. (2006). Sustainable urban transportation: Four innovative directions. Technology in Society, 28, 261-273. Doi: 10.1016/j.techsoc.2005.10.007.

Gospodini, A. (2005). Urban development, redevelopment and regeneration encouraged by transportation infrastructure projects: The case study of 12 European Cities. European Palnning Study, 13 (7), DOI: $10.1080 / 09654310500242121$.

Grabara, J. (2012). Urban Logistics in a Sustainable Development Concept on the Example of Transportation System in Gdynia City.

Grigg, N. (1988). Infrastructure Engineering and Management. John Wiley \& Sons.

Griškevičiūtè-Gečienèa, A, \& Griškevičienè, D. (2015). The Influence of Transportation Infrastructure Development on Sustainable Living Environment in Lithuania. 9th International Scientific Conference Transbaltica 2015: Procedia Engineering, 134, 215-223. DOI 10.1016/j.proeng.2016.01.062

Hairulsyah. (2013). The influence of public participation on sustainable transportation \& regional development in Medan (Unpublished doctoral dissertation). Faculty of Geography UGM and the Indonesian Geographers Association.

Hatcher, L. (1996). A Step-by-Step Approach to using the SAS System for Factor Analysis and Structural Equation Modeling. Cary, NC: SAS Institute, Inc.

Hayduk, L. A. (1987). Structural equation modeling with lisrel: Essential and advance. Baltimore. John Hopkin University.

He, L. (2007). Interregional Transportation, Trade, And Regional Comparative Advantage and Development in China (Unpublished doctoral dissertation). Faculty of Rensselaer Polytechnic Institute.

Hettne, B. (2001). Teori Pembangunan dan Tiga Dunia. Jakarta. Gramedia: Pustaka Utama.

Hickman, R. \& Hall, P. (2008). Moving the city east: Explorations into contextual public transportation-orientated development. Planning, Practice \& Research, 23(3). DOI: 10.1080/02697450802423583.

Hoyle, R. (1995). Structural Equation Modeling: Concepts, Issues, and Applications. Thousand Oaks, CA: Sage Publications. http://doi.org/10.1787/5k46hjm8jpmv-en.

Jaccard, J. \& Wan, C.K. (1995). Measurement error in the analysis of interaction effects between continuous predictors using multiple regression: multiple indicator and structural equation approaches. Psychological Bulletin, 117.

Jung, W., \& Buehler, R. (2013). Sustainable Transportation in Germany and the US: A comparison of the Washington, DC and Stuttgart Regions. Sustainable Transportation in Germany and the US 49th ISOCARP Congress 2013. 
Kennedy, C., Miller, E., Shalaby, A., Maclean, H. \& Coleman, J. The Four Pillars of Sustainable Urban Transportation. Transportation Review, 25(4), 393-414. DOI: 10.1080/0144164050015835.

Kenneth, A. Bollen \& Noble, M.D. (2011). Structural equation models and the quantification of behavior. Department of Sociology.

Khadiyanto, P. (2007). Partisipasi Masyarakat dalam Pembangunan Unit Sekolah. Semarang: Badan Penerbit UNDIP.

Lawrence W. LAN. (2005). Sustainable Development and Transportation: A Taiwan Perspective. Institute of Traffic and Transportation National Chiao Tung University.

Loehlin, J. C. (1997). Latent Variable Models. Mahwah, NJ: Lawrence Erlbaum Associates.

Maha, A. et al. (2014). Improvement and the quality and efficiency of public transportation: Strategies for the Procedia Economics and Finance, 15, 877-885.

Melo, P. C., Graham, D. J., \& Brage-Ardao, R. (2015). The productivity of transportation infrastructure investment: A meta-analysis of empirical evidence. 22nd International Economic Conference - IECS 2015 "Economic Prospects in the Context of Growing Global and Regional Interdependencies.

Miro, F. (1997). Sistem Transportationasi Kota Bandung. Penerbit Tarsito.

Naidu, G. (2008). Infrastructure Development in Malaysia. International Infrastructure Development in East Asia Towards Balanced Regional Development and Integration, ERIA Research Project Report.

Pokharel, R., \& Acharya, S. N. (2015). Sustainable Transportation Development in Nepal: Challenges, Opportunities and Strategies. Journal of the Eastern Asia Society for Transportation Studies, 11.

Samuelson, P. A., \& Nordhaus, W. D. (2001). Macroecomics: 17th Edition. The Mc. Graw-Hill Higher Education.

Sangadji, Mamang., E., \& Sopiah. (2010). Metodologi Penelitian Pendekatan Praktis dalam Penelitian. Yogyakarta: Andi.

Shim, G. E., Rhee, S. M., Ahn, K .H., \& Chung, S. B. (2006). The relationship between the characteristics of transportation energy consumption and urban form. Ann Reg Sci, 40, 351-367. DOI 10.1007/s00168-005-0051-5.

Sjafruddin, A. (2011). Pembangunan Infrastruktur Transportationasi untuk Menunjang Pembangunan Berkelanjutan Berbasis Ilmu Pengetahuan. Fakultas Teknik Sipil dan Lingkungan - ITB.

Snyder, C., \& Nicholson, W. (2007). Theory and Application of Intermediate Microeconomics, $10^{\text {th }}$ Edition. USA: Thomson South - Western

. (2012). Structural Equation Modeling Using AMOS an Introduction. The Division of Statistics Scientific Computation, The University of Texas at Austin.

SuescÚn, R. (2007). The Role of Fiscal Policy in Human Development and Growth. LAC Regional Study, Latin America and Carribean Region. The World Bank.

Sugiyono. (2003). Metode Penelitian Bisnis. CV. Alfabeta: Bandung.

Sugiyono. (2010). Metode Penelitian Kuantitatif Kualitatif \& RND. Bandung: Alfabeta.

Taliziduhu, N. (1990). Pengembangan Masyarakat: Mempersiapkan Masyarakat Tinggal Landa. Rineka Cipta.

Todaro, M. P. (2003). Economic Development. Essex: Pearson Education Limited.

Ubeka, M. K. (2015). Examples of Sustainable Development in the Area of Transportation. Procedia Economics and Finance, 27, 494 - 500. doi: 10.1016/S2212-5671(15)01026-6.

Van Den Berg, H. (2001). Economic Growth and Development. New York: McGraw-Hill/Irwin.

Vanessa, S., \& Mattisson, O. (2016). The Role of Public Transportation in Society-A Case Study of General Policy Documents in Sweden. Sustainability, 8. doi:10.3390/su8111120.

Wijeweera, A. (2009). Wagner's Law and Social Welfare: The Case of the Kongdom Saudi Arabia. Applied Econometrics and International Development, 9(2).

William, G. C. (1977). Sampling Techniques. Jakarta: Universitas Indonesia Press.

Yudhohusodo, S. (2002). Perumahan Untuk Seluruh Rakyat. Jakarta: Yayasan Padamu Negeri.

\section{Copyrights}

Copyright for this article is retained by the author(s), with first publication rights granted to the journal.

This is an open-access article distributed under the terms and conditions of the Creative Commons Attribution license (http://creativecommons.org/licenses/by/4.0/). 